\title{
Yield From Forest Harvesting Operations for the Production of Charcoal in the State of Minas Gerais
}

\author{
Guilherme Carvalho Lana ${ }^{1}$, Romano Timofeiczyk $\mathrm{Jr}^{2}$, Dimas Agostinho da Silva ${ }^{2}$, David Alexandre Buratto ${ }^{3}$ \\ \& Gustavo Silva Oliveira ${ }^{3}$ \\ ${ }^{1}$ Operations Manager, Wood Bio Energia, Sete Lagoas, Minas Gerais, Brazil \\ ${ }^{2}$ Department of Economics and Rural Extension, Federal University of Paraná, Curitiba, Paraná, Brazil \\ ${ }^{3}$ Graduate Program in Forest Engineering, Federal University of Paraná, Curitiba, Paraná, Brazil \\ Correspondence: Gustavo Silva Oliveira, Graduate Program in Forest Engineering, Federal University of Paraná, \\ Curitiba, Paraná, Brazil. Tel: 55-996-115-694. E-mail: gustavo_ccp@hotmail.com
}

Received: March 6, 2019

doi:10.5539/jas.v11n14p12
Accepted: June 3, $2019 \quad$ Online Published: August 31, 2019

URL: https://doi.org/10.5539/jas.v11n14p12

\begin{abstract}
The charcoal is a renewable natural resource, produced from wood by the process of carbonization and with great energetic importance. However, there is still little research and use of new technologies to optimize the use of wood in the production of charcoal. Therefore, the present work was aimed at analyzing the yield from forest harvesting operations for the production of charcoal. The research was developed at Vallourec e Mannesmann Florestal, a company located at Itapoã farm, municipality of Paraopeba, Minas Gerais. To this end, the harvest and timber transport operations in the short log system, the carbonization, and the properties of the charcoal produced were assessed. To this end, data was collected from eighteen 9-hour shifts for the Harvester, fifty-four 9-hour shifts for the forwarder, and 36 carbonization cycles. The equipment was analyzed working with three different log lengths $-2.1 \mathrm{~m}, 3.7 \mathrm{~m}$, and $5.0 \mathrm{~m}$. The results demonstrate, during the cutting and processing, that the yield by cutting longer logs is higher. Likewise, at forwarding, the operation's yield increases according to $\log$ length for thick and thin logs. Finally, concerning carbonization, the yield at the furnace loading stage was higher as the length of the log used increased, however, upon unloading the furnace, it was when it decreased.
\end{abstract}

Keywords: carbonization, processing, productivity

\section{Introduction}

The progressive demand for energy, coupled with the scarcity of natural resources, expose the need for renewable energy sources. Thus, wood appears as a biofuel by means of its woody material, becoming one of the leading possibilities for the provision of inputs in production processes (Lucena et al., 2011).

In this context, charcoal is a renewable natural resource, produced from wood by the carbonization process, which consists in the heat treatment of wood in a controlled atmosphere of oxygen (Frederico, 2009). Moreover, this feature has great economic importance for Brazil, contributing with $1.5 \%$ to the Brazilian Gross Domestic Product (GDP) in 2014 (Secretariat of Geology, Mining and Mineral Transformation-Sgm, 2015). Among the Brazilian states, Minas Gerais is one of the predominant centers of charcoal producers, standing out for also being a great consumer of charcoal, supplying the steel plants installed in the state (Rezende \& Santos, 2010).

It is known that the yield and the quality of charcoal are higher in wood with higher densities and high lignin contents (Vale et al., 2001). For Damásio et al. (2015) the quality of charcoal is related to the physical and chemical properties of the wood and to the carbonization activities.

Despite the energetic importance, there is still little research developments and the use of new technologies to optimize the use of wood in the production of charcoal (Oliveira et al., 2013). In this sense, the yield from charcoal production operations is directly influenced by the forest harvesting system adopted.

On this topic, the forest harvesting system commonly used in Brazil to produce charcoal occurs due to the reduction of labor dependence, better working conditions, reduction of the final cost of wood at the factory/production units and the need, by the industries, of a regular supply, and in increasingly quantities, of wood. 
Rezende et al. (1997) stated that to maintain themselves in increasing development, organizations in the forestry industry should focus primarily on optimizing these activities, improving product and service quality, reducing losses, improving equipment efficiency, maximizing productivity, and minimizing production costs. To this end, it becomes necessary to perform studies which consider the production processes of charcoal, according to the different forms of operation, quality, and yield of wood, for it presents itself as an efficient energy alternative. Among the works that deal with charcoal as an energy source are: Schmid et al. (2002); Darmstadt et al. (2000); Guo and Bustin (1998); Nishimiya et al. (1988).

Based on this context, the present work was aimed at analyzing the yield from forest harvesting operations for the production of charcoal in the state of Minas Gerais.

\section{Material and Methods}

\subsection{Study Area}

The study was conducted at Vallourec e Mannesmann Florestal, a company located at Itapoã farm, municipality of Paraopeba, Minas Gerais. The altitude at the site varies between 730 and 750 meters $\left(19^{\circ} 18^{\prime} \mathrm{W}, 44^{\circ} 30^{\prime} \mathrm{S}\right)$. The company operates in the primary sector with clones of the Eucalyptus spp. genus, intended for the production of charcoal. For this study, an 8-year-old natural hybrid clone of Eucalyptus urophylla was used, from a commercial field with $3 \times 3$ spacing, in slightly undulating terrain.

\subsection{Data Collection}

In this study, the harvest and timber transport operations in the short log system, carbonization, and the properties of the charcoal produced were assessed. To this end, data was collected from eighteen 9-hour shifts for the Harvester, fifty-four 9-hour shifts for the forwarder, and 36 carbonization cycles. The equipment was analyzed working with three different log lengths $-2.1 \mathrm{~m}, 3.7 \mathrm{~m}$, and $5.0 \mathrm{~m}$. First, a survey was conducted on the technical characteristics and conditions for using mechanized assemblies. Next, equipment productivity was determined working in different situations and using the "thin" and "thick" log separation system. This process is currently used by the company and it consists of separating the lower third of the tree as "thick" wood and the upper two-thirds as "thin" wood. The equipment always works in analogous situations of topography, forest productivity, and soil type, enabling the precise comparison between the processes under study.

\subsection{Characterization of Mechanized Forest Harvesting Operations}

The harvesting system used in the mechanized modules is the short log one, composed of the steps of cutting, processing wood in the field, forwarding, and transporting the timber to the carbonization plant.

For cutting and processing, Harvesters (forest tractors) were used. The equipment used was composed of a Caterpillar 320D L base machine, with net power of 138 HP, and a Komatsu Forest 370e head. The machines performed the activities of cutting, delimbing, and sectioning the wood into three determined lengths $(2.1 \mathrm{~m}, 3.7$ $\mathrm{m}$, and $5.0 \mathrm{~m}$ ), separating them into "thin" and "thick" logs. In this step, the volume of cut wood, the hours effectively worked, diesel oil consumption, lubricating oil consumption, and chain oil consumption were measured using the equipment's on-board computer.

For forwarding, Valtra BH 180 forwarders were used. Subsequently, the volume of transported timber, the hours effectively worked, and diesel oil consumption were measured using a cubing factor for each log length (this factor was determined by sampling the transported loads). These values were then used to make up the production costs. From this step, the number of treatments analyzed was doubled due to the separation between logs classified as "thick" and "thin", performed in the previous step.

For transporting the lumber, Volkswagen VW 242506 X2 self-loading trucks were used. Next, the transported mass was measured using a road scale.

\subsection{Carbonization Process}

In the carbonization process, three steps were analyzed: furnace loading, carbonization monitoring, and unloading. Subsequently, physical and chemical analyses of the charcoal produced were performed. Six rectangular FR 320 furnaces were used, whose maximum capacity is 230 st and the minimum is 160 st. The dimensions of the furnaces used were $14.31 \mathrm{~m}$ in length, $4.5 \mathrm{~m}$ wide, and ceiling height of $2.85 \mathrm{~m}$ (Figures 1 ). 


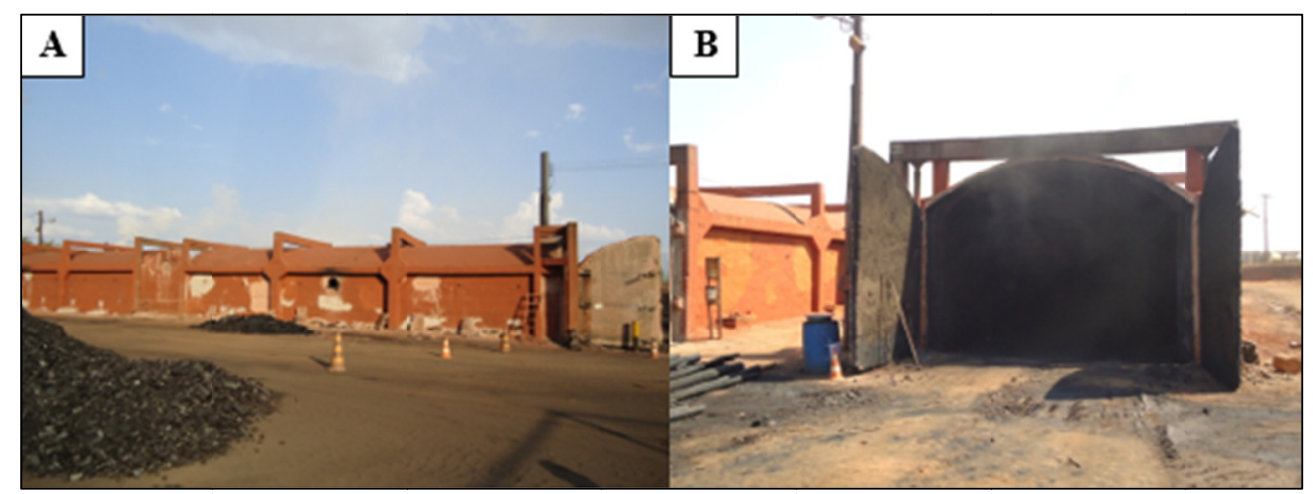

Figure 1. Carbonization stage in one of the FR 230 furnaces. A: Side view; B: Front view

\subsubsection{Furnace Loading and Unloading}

To load the furnace, a Volvo L60f wheel loader was used, fitted with a special crane. In this step, the hours worked and the timber mass moved were measured. As for unloading the furnace, a Volvo 160f wheel loader was used, fitted with a scale for determining the unloaded charcoal mass. The furnaces were open when the average temperature (monitored with the aid of the thermal profile) reached $60{ }^{\circ} \mathrm{C}$, a process currently used by the company in its commercial production. The generated firebrand mass was also measured using a road scale.

Charcoal storage was made in a previously marked area for each batch and covered with canvas, thus avoiding moisture. The total unloading time was determined from opening the furnace's door to the complete removal of the charcoal. In the furnace unloading step, the hours worked, the unloaded charcoal mass, and the firebrand mass generated in the process were measured.

\subsubsection{Analysis of Charcoal Quality}

The charcoal used for the physical and chemical analyses was collected inside the furnace, following the ABNT, NBR 6923/1981 standards. For each furnace, raw samples of 200 liters were collected. These analyses were conducted at the V\&M Florestal research center.

\subsubsection{Gravimetric Yield Gravimetric}

The gravimetric yields were determined according to (Equation 1) (Pimenta, 2000):

$$
\mathrm{RG}=\mathrm{PC} / \mathrm{PM} \times 100
$$

where, $\mathrm{RG}=$ gravimetric yield $(\%)$; $\mathrm{PC}=$ weight of the produced charcoal, dry base $(\mathrm{Kg})$; PM = weight of the timber into the furnace, dry base $(\mathrm{Kg})$.

\subsubsection{Fixed Carbon Yield}

For the fixed carbon yield, it was determined using Equation 2, described by Andrade (1989).

$$
\mathrm{RCF}(\%)=(\mathrm{RG} \times \mathrm{CF}) / 100
$$

where, $\mathrm{RCF}=$ fixed carbon yield $(\%) ; \mathrm{RG}=$ gravimetric yield in decimal form; $\mathrm{CF}=$ fixed carbon content $(\%)$.

\subsubsection{Ash Content}

The ash content was determined according to the ABNT, NBR 8112/1986 standards. To this end, the material sample was taken to the preheated furnace at $600{ }^{\circ} \mathrm{C} \pm 10^{\circ} \mathrm{C}$ for 6 hours until its complete calcination. The sample was then removed and cooled in a desiccator and weighed afterwards. The equation used to calculate the ash content was as follows:

$$
\mathrm{CZ}=\mathrm{Ms} / \mathrm{Mr} \times 100
$$

where, $\mathrm{CZ}=$ charcoal ash content $(\%) ; \mathrm{Mr}=$ residue (ash) weight, in $\mathrm{g}$; $\mathrm{Ms}=$ mass of the over-dried sample, in $\mathrm{g}$.

\subsubsection{Volatile Materials}

The content of volatile materials was determined according to the ABNT, NBR 8112/1986 standards. To this end, the material sample was taken to a furnace, which had been preheated to $950{ }^{\circ} \mathrm{C} \pm 10{ }^{\circ} \mathrm{C}$. Initially, the capped crucible was placed with $1 \mathrm{~g}$ of sample material on the furnace's door, leaving it there for three minutes. Next, the crucible was placed inside the furnace and the door closed for eight minutes. The sample was then removed 
and cooled in a desiccator, being weighed afterwards. The calculation of the volatile material content is described by Equation 4:

$$
\mathrm{MV}=(\mathrm{Ms}-\mathrm{Mv}) / \mathrm{Ms} \times 100
$$

where, $\mathrm{MV}=$ volatile material content (\%); Ms = initial mass of the furnace-dried sample, in $\mathrm{g}$; $\mathrm{Mv}=$ final mass of the sample, in $\mathrm{g}$.

\subsubsection{Fixed Carbon Content}

The fixed carbon content was determined according to the ABNT, NBR 8112/1986 standards, according to Equation 5:

$$
\mathrm{CF}=100-(\mathrm{CZ}+\mathrm{MV})
$$

where, $\mathrm{CF}=$ fixed carbon content $(\%) ;=\mathrm{CZ}$ ash content $(\%) ; \mathrm{MV}=$ volatile material content $(\%)$.

\subsubsection{Granulometry}

The granulometric analysis was performed according to the ABNT, NBR 7402/1982 standards. First, $10 \mathrm{~kg}$ of charcoal was placed in the top sieve of the vibrating equipment. Next, the equipment was turned on for 5 minutes and, then, each charcoal fraction, retained in the respective sieves, was weighed and the percentage that each mass represented from the initial mass was calculated. To obtain the granulometry, Equation 6 was used.

$$
\mathrm{TM}=[\mathrm{B}(\mathrm{a}-\mathrm{c})+\mathrm{C}(\mathrm{b}-\mathrm{d})+\ldots+\mathrm{L}(\mathrm{k}-\mathrm{m})+100 \times 1] \times 0.005
$$

where, $\mathrm{TM}=$ Average particle size $(\mathrm{mm}) ; \mathrm{a}, \mathrm{b}, \mathrm{c}, \mathrm{d} . . \mathrm{k}, \mathrm{l}, \mathrm{m} .=$ mesh opening $(\mathrm{mm}) ; \mathrm{A}, \mathrm{B}, \mathrm{C}, \mathrm{D}, \ldots, \mathrm{K}, \mathrm{L}, \mathrm{M} .=$ accumulated percentages (\%).

\subsubsection{Mechanical Strength}

The charcoal's mechanical strength was determined by the breakage and abrasion indexes, using the drum and drop test methods. The performance of these tests was according to the ABNT NBR 7416/1984 and 8740/1985 standards. To perform the drop test, $10 \mathrm{~kg}$ of charcoal was set aside in proportion to the sample's granulometric fractions. Next, it was placed in the drop test equipment and raised to a height of $1.83 \mathrm{~m}$. Upon reaching the set height, the material was subjected to a free fall. The drop procedure was repeated three times. Finally, the material was subjected to a granulometric test, according to the ABNT NBR 7402/1982 standards. The equation used for determining the breakage index by the drop teste was number 7 :

$$
\mathrm{IQ}=[1-(\mathrm{f} / \mathrm{F})] \times 100
$$

where, $\mathrm{IQ}=$ drop breakage index $(\%) ; \mathrm{f}=$ average fragment after the test; $\mathrm{F}=$ the average fragment after the test.

\subsubsection{Drum Test}

To perform the drum test, $10 \mathrm{~kg}$ of charcoal was set aside in proportion to the sample's granulometric fractions. Next, it was placed inside the testing equipment's drum and subjected to 150 rotations. Finally, the material was subjected to a new granulometric test, according to the ABNT NBR 7402/1982 standards. In Equation 8, the procedure for determining the breakage index by the drum test is described.

$$
\text { IT }=[1-(\mathrm{f} / \mathrm{F})] \times 100
$$

where, IT $=$ breakage and abrasion by drum test $(\%) ; \mathrm{f}=$ average fragment after the test; $\mathrm{F}=$ the average fragment before the test.

\subsubsection{Higher Calorific Value}

The higher calorific value was estimated using the Goutal equation (Mendes et al., 1982 cited by Sater et al., 2011), as described in Equation 9.

$$
\mathrm{PCS}=82 \mathrm{CF}+(\mathrm{MV} \times \mathrm{A})
$$

where, $\mathrm{PCS}=$ Higher calorific value $(\mathrm{kcal} / \mathrm{kg}) ; \mathrm{CF}=$ fixed carbon content $(\%) ; \mathrm{MV}=$ volatile material content (\%); $\mathrm{A}=$ coefficient given by the $\mathrm{MV} /(\mathrm{MV}+\mathrm{CF})$ ratio.

\section{Results and Discussions}

The results are presented and discussed in the same sequence as the operations of the harvesting system for the production of charcoal to occur, i.e., first, the results of the mechanized cutting with the Harvester are dealt with, next, the forwarding stage with the Forwarder, and then the carbonization stage. 


\subsection{Timber Harvest and Transport}

\subsubsection{Timber Cutting and Processing in the Field}

It is ascertained that the equipment's yield is higher upon sectioning $5.0 \mathrm{~m}$ and $3.70 \mathrm{~m}$ logs, in comparison with the equipment's yield upon sectioning $2.10 \mathrm{~m}$ logs (Figure 2).

As the yield is directly affected by the number of activities performed by the equipment, by sectioning shorter logs, a greater number of activities per tree is performed. Therefore, the Harvester's yield, upon sectioning shorter logs, is smaller in comparison with the same equipment upon sectioning longer logs. Considering that the Harvesters are machines designed to work with $\operatorname{logs}$ of $2.0 \mathrm{~m}$ to $6.0 \mathrm{~m}$ in length and that the yield increased upon increasing log length, the yield curve of this machine, due to the increased length of the log, is close to the optimum point upon working with logs of $3.70 \mathrm{~m}$ and $5.0 \mathrm{~m}$ in length, not displaying greater increases in productivity upon varying log lengths from $3.70 \mathrm{~m}$ to $5.0 \mathrm{~m}$.

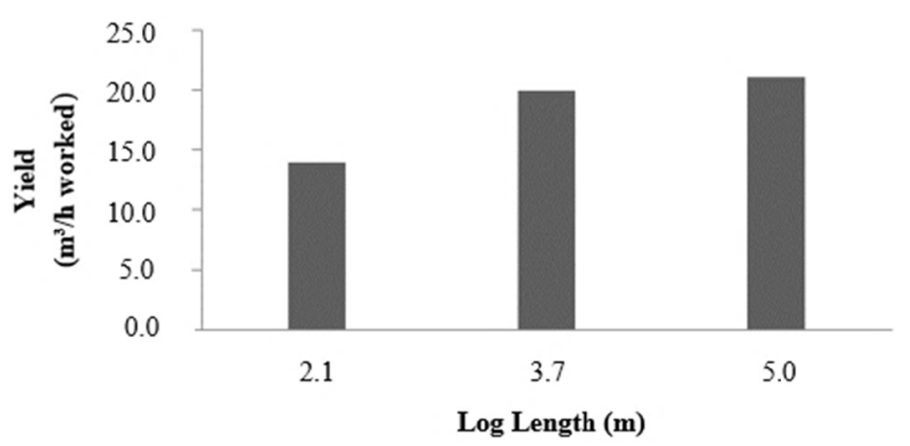

Figure 2. The Harvester's yield in eucalyptus harvesting in logs with three lengths $\left(\mathrm{m}^{3} / \mathrm{h}\right.$ worked)

The highest yield in $\mathrm{m}^{3} / \mathrm{h}$ worked is achieved upon sectioning logs of $5.0 \mathrm{~m}$ in length $\left(21.02 \mathrm{~m}^{3} / \mathrm{h}\right.$ worked $)$, a lower yield in comparison with the yield of $28.00 \mathrm{~m}^{3} / \mathrm{h}$ worked found by Burla, 2008, upon analyzing the work of a John Deer Harvester model 1270 D, $6 \times 6$ drive, fitted with tires and a $160 \mathrm{Kw}$ engine, and with a $762 \mathrm{C}$ cutting head, sectioning logs at $4.4 \mathrm{~m}$ lengths. This increased productivity can be explained by the greater agility that the Harvester fitted with tires has in moving around, in comparison with the one equipped with tracks, in terrains in which machines move with ease. Simões (2010) in a study on the productivity of a Harvester composed by a John Deer 200 C LC base machine with a hydraulic excavator structure, equipped with a $6080 \mathrm{H}$ diesel engine, with $119 \mathrm{~kW}$ with tracks, achieved a productivity of 18.72 to $39.71 \mathrm{~m}^{3} / \mathrm{h}$ worked of debarked timber with $6.0 \mathrm{~m}$ in length. Silva et al., (2011) found a productivity of $18.57 \mathrm{~m}^{3} / \mathrm{h}$ worked upon analyzing the productivity of a Komatsu PC 200 LC Harvester, numbers like those measured in this study. In another study performed with the same equipment and log length by Silva et al. (2011), the Harvester yielded $14.79 \mathrm{~m}^{3} / \mathrm{h}$ worked with $\operatorname{logs}$ of $2.10 \mathrm{~m}$ in length, of $17.58 \mathrm{~m}^{3} / \mathrm{h}$ worked with $\operatorname{logs}$ of $3.70 \mathrm{~m}$ in length, and $20.95 \mathrm{~m}^{3} / \mathrm{h}$ worked with logs of 5.0 in length. This study was conducted in areas with different productivity and slopes, factors that explain the variation found in yield.

Figure 3 shows the log length with fuel consumption ratio. Thus, the greater the length of the log, the larger the diesel consumption and, hence, the greater the expenses with hydraulic oil and maintenance, due to the greater effort of the equipment to section the longer logs. 


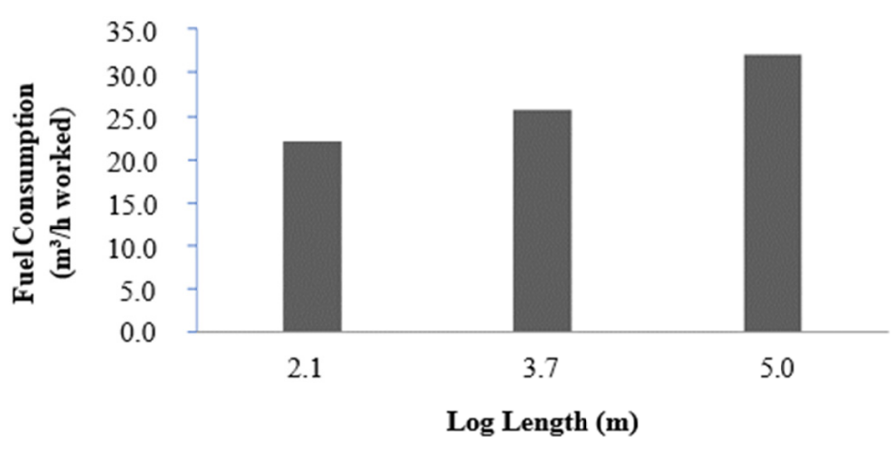

Figure 3. The Harvester's fuel consumption in eucalyptus harvesting in logs with three lengths per hour worked ( $1 / \mathrm{h}$ worked)

Simões et al. (2010), in his study with a Harvester composed of a Caterpillar CAT 320 CL base machine with a hydraulic excavator structure with a wheelset system composed of tracks, equipped with a 3066-T diesel motor, with $103 \mathrm{~kW}$, found a consumption of $24 \mathrm{l} / \mathrm{h}$ worked upon cutting an eucalyptus forest, with a $3 \mathrm{~m} \times 2 \mathrm{~m}$ spacing, 72 months old, on a flat and slightly undulating terrain, and a volume of $0.22 \mathrm{~m}^{3} /$ tree and sectioning logs with $6.0 \mathrm{~m}$ in length. The consumption found by the author is less in comparison with the consumption of this study, due to variations in the characteristics of the forest used, mainly because of the relief worked being flat and the volume being smaller than the volume of $0.29 \mathrm{~m}^{3} /$ tree of the forest area used in this study.

Figure 4 shows the hydraulic oil consumption and the chain oil consumption of the Harvester in $1 / \mathrm{h}$ worked.
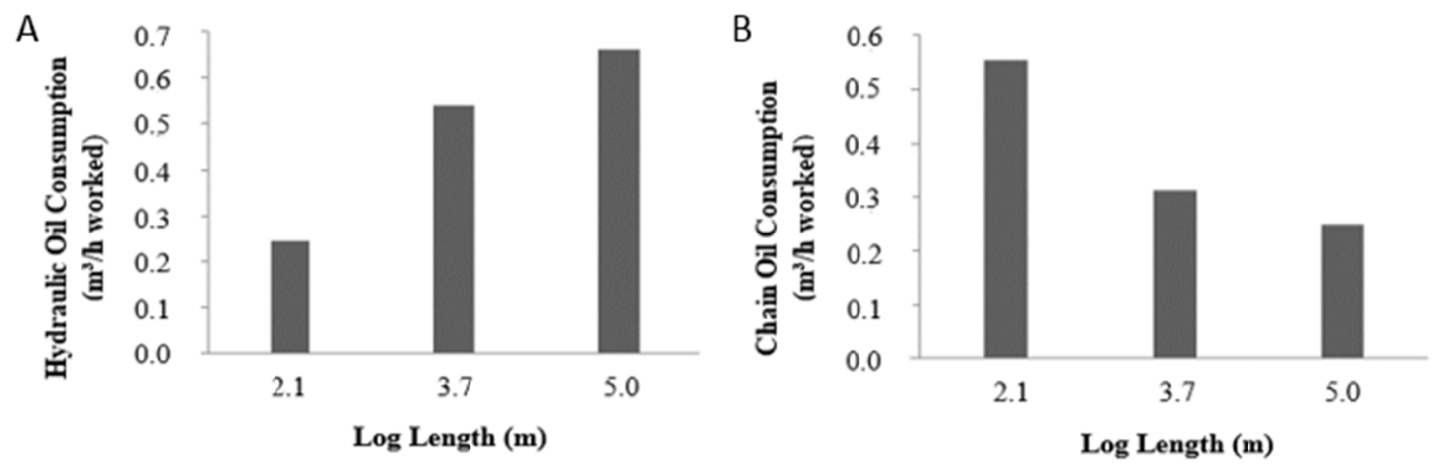

Figure 4. A) Hydraulic oil consumption of the Harvester in harvesting eucalyptus in logs of three lengths per hour worked (1/h worked); B) Chain oil consumption of the Harvester in harvesting eucalyptus in logs of three lengths per hour worked ( $1 / \mathrm{h}$ worked)

It can be seen in Figure 4a, a higher consumption of hydraulic oil in longer logs, due to the greater effort by part of the equipment to handle the logs. Relative to the chain oil consumption (Figure 4b), the consumption is higher upon working with shorter logs, since a greater number of cuts is needed to process a tree in shorter lengths.

\subsubsection{Forwarding}

Figure 5 presents the yield of the forwarder in the transport of eucalyptus in logs of three lengths and with separation between thin and thick $\operatorname{logs}\left(\mathrm{m}^{3} / \mathrm{h}\right.$ worked). 


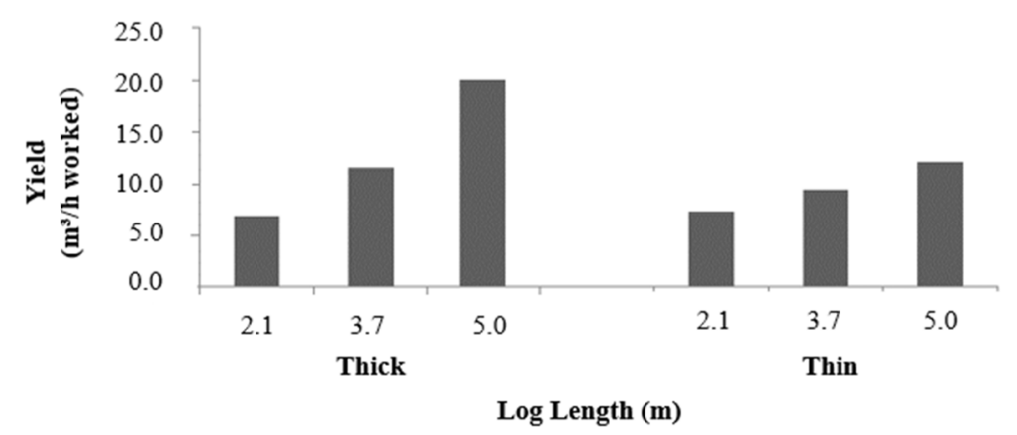

Figure 5. Yield of the forwarder tractor in the transport of eucalyptus in logs of three lengths and with separation between thin and thick $\operatorname{logs}\left(\mathrm{m}^{3} / \mathrm{h}\right.$ worked $)$

The yield of the operation increases according to log length, both in operation with thick logs and thin logs. The forwarding yield, observed in working with longer logs, can be explained by the greater volume handled by the crane in these lengths, during loading and unloading operations. Minette et al. (2008) on a technical assessment study of logging with a forwarder, achieved a productivity of $23.83 \mathrm{~m}^{3} / \mathrm{h}$ worked upon transporting logs of 2.80 $\mathrm{m}$ in length, value which is greater than the yield found in this work, of $20.0 \mathrm{~m} / \mathrm{h}$ worked upon transporting $\operatorname{logs}$ of $5.0 \mathrm{~m}$ in length.

Fuel oil consumption of the forwarder varied according to the increase in log length (Figure 6).

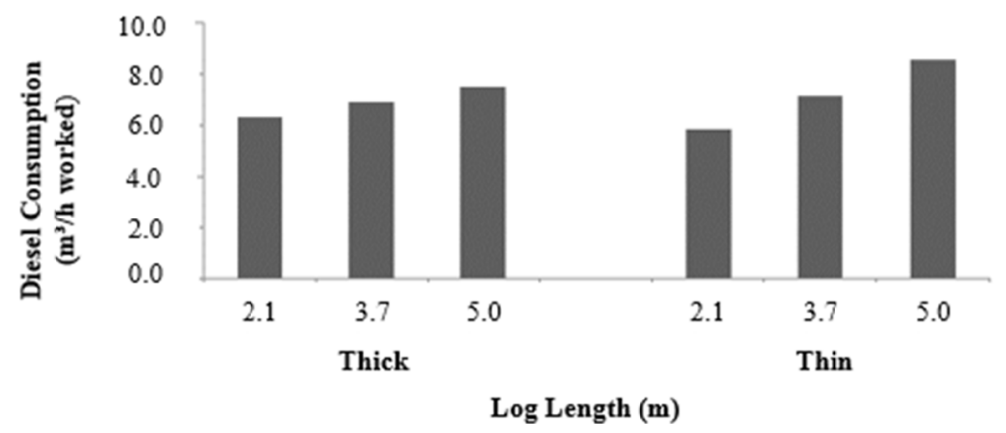

Figure 6. Hourly diesel oil consumption of the forwarder in the transport of eucalyptus in logs of three lengths

( $1 / \mathrm{h}$ worked)

The increased consumption was due to the greater effort upon handling longer logs and by the improved accommodation of the load with longer logs. Loads with longer logs feature less empty or unfilled spaces, mainly due to the dimensions of the equipment used, for being designed to work with logs of $5 \mathrm{~m}$ in length. Sauerbier (2011) in his study found an average diesel oil consumption of an equipment composed of a New Holland TM 7010 tractor, and a TMO AC 5610 forwarder of $13.0 \mathrm{l} / \mathrm{h}$ worked, this value being greater when compared with the one found in this study. This was ascertained, due to the New Holland TM 7010 tractor having $141 \mathrm{CV}$ of power and the Valtra BH 180 tractor, used in the experiment, having $189 \mathrm{CV}$ of power, significant difference when comparing the two models working with a forwarder, since tractors with more power are subjected to less effort during work, thus generating less fuel oil consumption.

\subsection{Carbonization and Charcoal Quality}

The average results of the carbonization stage and of the analyses concerning charcoal quality are shown in Table 1. 
Table 1. Average results of the carbonization stage obtained for each treatment

\begin{tabular}{|c|c|c|c|c|c|c|}
\hline \multirow{3}{*}{ Variables } & \multicolumn{6}{|c|}{ Treatments } \\
\hline & \multicolumn{3}{|c|}{ Thin $(\mathrm{m})$} & \multicolumn{3}{|c|}{ Thick (m) } \\
\hline & 2.1 & 3.7 & 5.0 & 2.1 & 3.7 & 5.0 \\
\hline \multicolumn{7}{|l|}{ Timber } \\
\hline Moisture (\% B.S) & 23.0 & 16.0 & 26.0 & 39.0 & 40.0 & 54.0 \\
\hline Basic density $\left(\mathrm{kg} / \mathrm{m}^{3}\right)(\mathrm{B} . \mathrm{S})$ & 495.0 & 495.0 & 495.0 & 495.0 & 495.0 & 495.0 \\
\hline Diameter $(\mathrm{cm})$ & 11.1 & 10.1 & 10.1 & 15.2 & 15.1 & 15.6 \\
\hline Length $(\mathrm{m})$ & 2.1 & 3.7 & 5.0 & 2.1 & 3.7 & 5.0 \\
\hline \multicolumn{7}{|l|}{ Carbonization } \\
\hline Average loading time (h) & 5.2 & 3.2 & 2.1 & 4.5 & 3.0 & 2.1 \\
\hline Dry mass into the furnace $(\mathrm{t})$ & 70.0 & 61.9 & 54.6 & 65.0 & 58.3 & 53.5 \\
\hline Average unloading time $(\mathrm{h})$ & 2.7 & 2.5 & 2.3 & 2.7 & 2.6 & 2.5 \\
\hline \multicolumn{7}{|l|}{ Gravimetric } \\
\hline Yield (\% B.S) & 30.1 & 31.6 & 30.9 & 32.6 & 31.8 & 31.7 \\
\hline Fixed carbon yield (\%) & 11.4 & 11.2 & 9.4 & 12.8 & 13.2 & 12.7 \\
\hline \multicolumn{7}{|l|}{ Charcoal } \\
\hline Produced charcoal mass $(\mathrm{t})$ & 21.1 & 19.6 & 16.9 & 21.2 & 18.6 & 17.0 \\
\hline Produced firebrand mass $(\mathrm{t})$ & 8.6 & 5.7 & 6.2 & 7.0 & 8.7 & 9.3 \\
\hline Ash content $(\%)$ & 0.77 & 0.73 & 0.66 & 0.60 & 0.50 & 0.72 \\
\hline Volatile material content $(\%)$ & 17.5 & 21.1 & 23.5 & 16.7 & 21.7 & 17.8 \\
\hline Fixed carbon content $(\%)$ & 81.7 & 78.1 & 75.9 & 82.7 & 77.8 & 81.5 \\
\hline Granulometry (mm) & 51.0 & 48.0 & 49.1 & 52.3 & 51.2 & 43.6 \\
\hline Breakage by the drop test index $(\%)$ & 19.3 & 18.0 & 19.3 & 19.7 & 30.6 & 28.9 \\
\hline Breakage by the drum test index $(\%)$ & 52.3 & 49.0 & 43.4 & 57.0 & 59.6 & 61.2 \\
\hline Calorific value (Kcal/kg) & 8688.9 & 8710.5 & 8731.3 & 8732.6 & 8792.5 & 8703.1 \\
\hline
\end{tabular}

The yield of the furnace loading stage was higher as the length of the log used increased (Figure 7). This increase is due to the lower number of maneuvers needed for the complete filling of the furnace, by working with longer logs, since, in order to completely fill the furnace with shorter logs, it is necessary to organize more stacks inside the furnace.

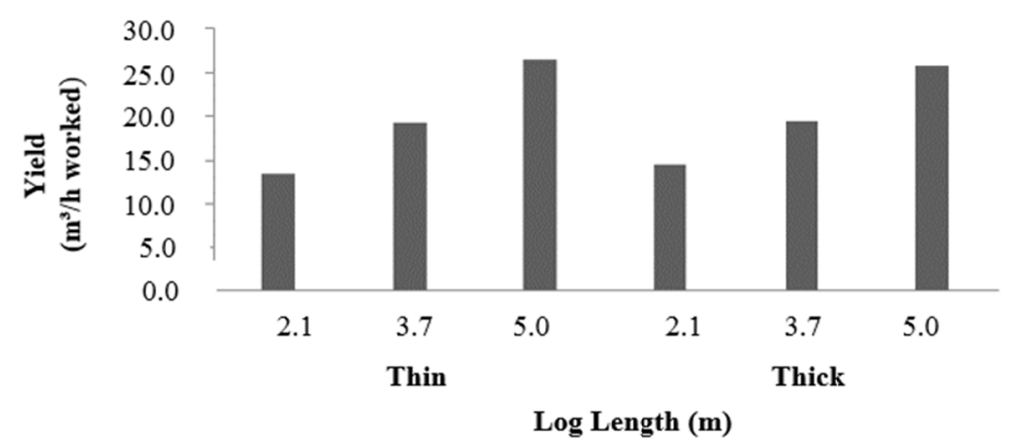

Figure 7. Yield of the furnace loading operation $(\mathrm{t} / \mathrm{h})$ in different treatments

Therefore, longer logs are more desirable from a yield point of view at the furnace loading stage. However, they showed lower yield at the furnace unloading step, due to the greater volume of charcoal produced by these furnaces and the smaller volume of firebrands generated (Figure 8). 


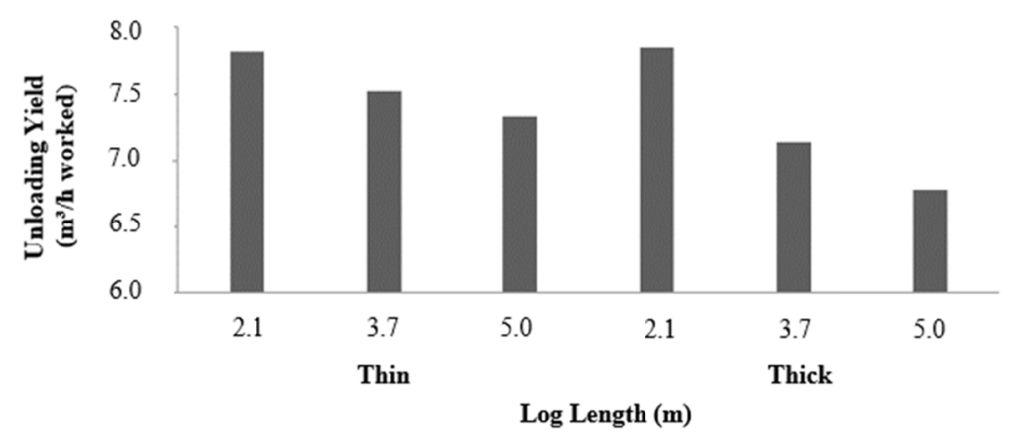

Figure 8. Yield of the furnace unloading operation $(\mathrm{t} / \mathrm{h})$ in different treatments

The dry mass placed into the furnace, for treatment, was smaller as the length of the log increased, since, with shorter logs, the accommodation of the load in the furnace is better, when compared with longer logs, since the equipment presents greater ease in handling shorter logs.

Moisture content in thick logs is greater when compared to contents in thin logs. This moisture content is due to the drying process being faster when compared with logs of greater diameters, and it can also be explained by the stacking of thin logs in the drying process. Inside these stacks, there are more empty spaces, providing enhanced air circulation and, consequently, favoring drying. It may be noted as well that in timber classified as thick, the moisture content increases according to the length of the logs, since timber dries by the ends, and the greater the length, the longer the drying process takes.

The gravimetric yield did not vary significantly between treatments, due to the homogeneity of the material used and the carbonization process being the same for all treatments, in addition to the furnaces and the carbonization process being the same. The charcoal mass and firebrand mass produced presented the same behavior in comparison to dry mass into the furnace, i.e., varied. Increasing the mass of the timber put into the furnace, increases the mass of the charcoal and firebrand produced. This logic explains the homogeneity of the gravimetric yield.

The quality parameters of the charcoal were not affected by the variation in the length of the log used and are within the desirable range for use in blast furnaces. The samples used showed high homogeneity because they belong to the same clone, having the same age and being derived from a field where nutrition, management, and the weather regimen were the same.

\section{Conclusions}

In cutting and processing, equipment productivity increases with the use of longer logs. Similarly, the hourly fuel and hydraulic oil consumption of the equipment increases with the use of longer logs. Concerning the consumption of chain oil, it is higher when processing shorter logs.

During forwarding, the yield and diesel consumption are higher in longer logs, due to the greater effort of the cranes in handling longer logs and by the improved accommodation of the load with longer logs.

Concerning carbonization and its quality, the yield at the furnace loading stage was higher as the length of the $\log$ used increased, however, upon unloading the furnace, it was when it decreased.

Given the above, the system operating with longer logs is the most recommended one for the production of charcoal.

\section{References}

ABNT (Associação Brasileira de Normas Técnicas). (1981). NBR 6923/81-Carvão vegetal-Amostragem e preparação da amostra. Rio de Janeiro, RJ.

ABNT (Associação Brasileira de Normas Técnicas). (1982). NBR 7402/82-Carvão vegetal-Determinação granulométrica. Rio de Janeiro, RJ.

ABNT (Associação Brasileira de Normas Técnicas). (1984). NBR 7416/84-Carvão vegetal-Determinação do indice de quebra. Rio de Janeiro, RJ.

ABNT Associação Brasileira de Normas Técnicas). (1985). NBR 8740/85-Carvão vegetal-Determinação do indice de quebra e abrasão. Rio de Janeiro, RJ. 
ABNT (Associação Brasileira de Normas Técnicas). (1986). NBR 8112/86-Carvão vegetal-Análise imediata. Rio de Janeiro, RJ.

Andrade, A. M. (1989). Influencia da casca de Eucalyptus grandis W. Hill ex Maiden no rendimento e qualidade de carvão vegetal (p. 86, Dissertação, Mestrado em Ciência Florestal, Viçosa, MG, Brazil).

Burla, E. R. (2008). Avaliação técnica e econômica do "Harvester" na colheita do Eucalipto (p. 62, Dissertação, Mestrado em Ciência Florestal Viçosa, MG, Brazil).

Damásio, R. A. P., Oliveira, A. C., Carneiro, A.C. O., Barcelos, D. C., Pereira, B. L. C., Magalhaes, M. A., \& Silva, C. M. S. (2015). Perfil térmico e controle da carbonização em forno circular por meio da temperatura interna. Ciência da Madeira, 6(1), 11-22. https://doi.org/10.12953/2177-6830/rcm.v6n1p11-22

Darmstadt, H., Pentea, D., Summchen, L., Roland, U., Kaliaguine, S., \& Roy, C. (2000). Surface and bulk chemistry of charcoal obtained by vacuum pyrolysis of bark: influence of feedstock moisture content. Journal of Analytical and Applied Pyrolysis, 53, 1-17. https://doi.org/10.1016/S0165-2370(99)00051-0

Frederico, P. G. U. (2009). Efeito da região e da madeira de eucalipto nas propriedades do carvão vegetal (p. 86, Dissertação, Mestrado em Ciências Florestais, Universidade Federal de Viçosa, Viçosa, MG, Brazil).

Guo, Y., \& Bustin, R. M. (1988). FTIR spectroscopy and reflectance of modern charcoal and fungal decayed wood: Implications for studies of inertinite in coals. International Journal of Coal Geology, 37, 29-53. https://doi.org/10.1016/S0166-5162(98)00019-6

Lucena, L. P., Kliemann Neto, F. J., Massuia, F. M., \& Freitas, C. E. (2011). A demanda por carvão vegetal e suas consequências econômicas sobre o agronegócio do eucalipto no Brasil. Revista de Estudos Sociais, 13(25), 158-172.

Mendes, M. G., Gomes, P. A., \& Oliveira. J. B. de. (1982). Propriedades e controle de qualidade do carvão vegetal. Produção e utilização de carvão vegetal (pp. 75-90). Belo Horizonte: CETEC.

Minette, L. J., Silva, E. N., Miranda, G. M., Souza, A. P., \& Fiedler, N. C. (2008). Avaliação técnica da operação de extração de Eucalyptus SSP. Utilizando o trator autocarregável e o trator florestal transportador "Forwarder" na região sul da Bahia. Revista Engenharia na Agricultura, 16(3), 312-317. https://doi.org/ 10.13083/1414-3984.v16n03a05

Nishimaya, K., Hata, T., Imamura, Y., \& Ishihara, S. (1998). Analysis of structure of wood charcoal by X-ray photoelectron spectroscopy. The Japan Wood Science, 44, 56-61. https://doi.org/10.1007/BF00521875

Oliveira, A. C., Carneiro, A. C. O., Barcellos, D. C., Rodriguez, A. V., Amaral, B. M. N., \& Pereira, B. L. C. (2015). Resfriamento artificial em fornos retangulares para a produção de carvão vegetal. Revista Árvore, 39(4), 769-778. https://doi.org/10.1590/0100-67622015000400020

Pimenta, A. S. (2000). Produção de carvão vegetal. Viçosa: UFV.

Rezende, J. B., \& Santos, A. C. D. (2010). A cadeia produtiva do carvão vegetal em Minas Gerais: Pontos críticos e potencialidades (p. 82). Viçosa, MG: EPAMIG.

Rezende, J. L., Fiedler, N.C., Mello, J. M., \& Souza, A. P. (1997). Análise técnica e de custos de métodos de colheita e transporte florestal (Dissertação, Mestrado em Ciência Florestal Lavras, UFLA, Brazil).

Sauerbier, W. (2011). Interface de decisão sobre a aquisição ou aluguel de máquinas florestais com base no custo operacional (p. 35). Irati, PR: Unicentro. Monografia em Ciência Florestal.

Schmid, E. M., Skjemstad, J. O., Glaser, B., Knicker, H., \& Kogel, I. (2002). Detection of charred organic matter in soils from a Neolithic settlement in Southern Bavaria, Germany. Geoderma, 107, 71-91. https://doi.org/ 10.1016/S0016-7061(01)00139-2

SGM (Secretaria de Geologia, Mineração e Transformação Mineral). (2015). Anuário Estatístico: Setor Metalúrgico (p. 108). Brasília.

Silva, E. N., Machado, C. C., Fiedler, N. C., Paula, M. O., \& Fialho, A. C. (2011). Produtividade no corte com Harvester em colheita de eucalipto no sul do Espirito Santo (pp. 263-265). XVI Seminário de atualização em sistemas de colheita de madeira e transporte florestal, Campinas. Anais... Curitiba: FUPEF, UFPR.

Simões, D., \& Fenner, P. T. (2010). Influência do relevo na produtividade e custos do Harvester. Revista Scientia Florestalis, 38(85), 107-114.

Vale, A. T., Costa, A. F., Gonçalves, J. C., \& Nogueira, M. (2001). Relação entre a densidade básica da madeira, o rendimento e a qualidade do carvão vegetal de espécies do cerrado. Revista Árvore, 25(1), 89- 95. 


\section{Copyrights}

Copyright for this article is retained by the author(s), with first publication rights granted to the journal.

This is an open-access article distributed under the terms and conditions of the Creative Commons Attribution license (http://creativecommons.org/licenses/by/4.0/). 